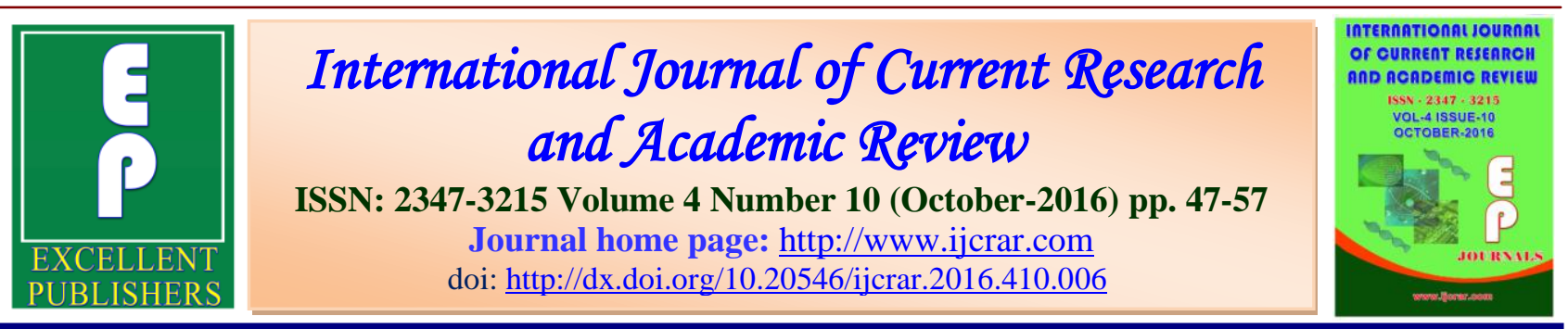

\title{
Production of Bio-Oil in Nigeria: Challenges and Prospects
}

\author{
Julius C. Ahiekpor ${ }^{1,2}$, Ayoade O. Kuye ${ }^{3}$ and Osei-Wusu Achaw ${ }^{2}$ \\ ${ }^{1}$ World Bank Centre of Excellence, Institute of Petroleum Studies, University of Port \\ Harcourt, Nigeria \\ ${ }^{2}$ Chemical Engineering Department, Kumasi Technical University, Ghana \\ ${ }^{3}$ Chemical Engineering Department, University of Port Harcourt, River state, Nigeria \\ *Corresponding author
}

KEYWORDS
Bio-oil,
lignocellolusic,
biomass,
fast pyrolysis,
challenges,
Nigeria

\section{A B $\mathbf{S}$ T $\mathbf{R}$ A $\mathbf{C}$ T}

The Biofuels Policy and Incentives of Nigeria and the Petroleum Technology Development Fund (PTDF) provide opportunities for converting waste lignocellolusic materials to bio-oil. This paper evaluates the technical challenges that confront the production of bio-oil from locally sourced materials in Nigeria using fast pyrolysis. The paper illustrates fast pyrolysis process; highlighting the different types of reactors available for the process and establishes their comparative advantages and limitations. The design of reactor, workshop for fabrication of equipment, operation, feedstock supply and improving the bio-oil quality and yield, were identified as major constraints to the production of bio-oil locally. This paper concludes that adopting a learning curve approach through research by the design, fabrication, operation and optimization of bench scale pyrolysis systems can serve as a basis to understand and solve the challenges associated with fast pyrolysis such as heat supply and heating rate, char removal, rapid vapour cooling, and vapour residence time.

\section{Introduction}

\section{Background}

The importance of sustainable alternatives energy development has increased globally in recent years. This has led to several countries; developed and developing, instituting and mandating laws and policies to replace varying proportions of fossil based fuels consumed annually by biofuels.
It is estimated that about 117 billion liters of biofuels was consumed globally in 2013 (REN21, 2014). Although the contribution from Africa is not much, most African countries are thriving to contributing to this effort (Antwi et al., 2010). In 2007, the Renewable Energy Master Plan was launched in Nigeria to provide a framework for increasing renewable energy in the country's energy mix (Popoola et al., 2013). 
As a result, it is projected that about 1.3 billion litres of biofuels is needed annually by the year 2020 to achieve its $10 \%$ fossil fuel replacement targets (NNPC, 2007).

Producing biofuels from animal or plant sources (food and non-food crops) is called first generation biofuel. Although firstgeneration technology is considered mature with many commercial facilities being installed, this is not an option for Nigeria presently since it is a net importer of food (Izah and Ohimain, 2013) and following such a route may lead to food scarcity and insecurity. An alternative is to convert the abundant biomass resources which are generated daily as waste to biofuels. These biofuels are referred to as second generation biofuels. The development of second generation biofuels from lignocellulose sources, such as nonedible plant materials (biomass) has received a lot of attention recently since it provides some advantages over biofuels from food crops (first generation) including including greater reductions in greenhouse gas emissions, reduced land-use requirements, less competition for land, food, fiber, and water, and solving waste disposal problems (Mitchell, 2011; Kemausuor, 2014). It is expected that biomass energy would continue to play a pivotal role in the world's future energy supply (IEA, 2010; Isahak et al., 2012). Already, biomass accounts for about 10 percent of the worlds energy supply (Vakkilainen et al., 2013). This is even higher for developing countries such as Nigeria where biomass supplies about twothirds of energy services usually through inefficient forms, particularly for cooking and heating (Kuye and Edeh, 2013).

To continue to contribute sustainably to the world's energy demand, biomass must be converted efficiently to forms that can easily be transported and upgraded for several applications including biofuel and chemicals. Although, this is currently being done in most industrialized and emerging countries on largely pilot basis with a few commercial plants commissioned for continued advancement of the technology, very little is being done in most sub-saharan African (SSA) countries such as Nigeria. These SSA countries have abundant biomass resources and agricultural residue (waste). For instance, there are over two thousand wood mills (wood processing plants) all over Nigeria generating $104,000 \mathrm{~m}^{3}$ of agroforestry waste daily (Aina, 2006; Iderawumi et al., 2012). The sawdust is heaped and burnt as waste at these wood mills posing environmental and health challenges (Okorie et al., 2015).

The Petroleum Technology Development Fund (PTDF) of Nigeria, as part of its mandate for encouraging the development of indigenous technologies for renewable energy, provides research grants for the production of bio-oil from agro-forestry wastes. Consequently, the PTDF Biofuels research laboratory at the University of Port Harcourt in Nigeria, has since 2012 been studying the conversion of sawdust to biooils using fast pyrolysis. The aim of this paper is to highlight some of the technical challenges that confront the production of bio-oil from locally sourced materials in Nigeria using fast pyrolysis. The paper also seeks to give an overview of fast pyrolysis process highlighting the different types of reactors available for the process to establish their comparative advantages and limitations.

\section{Fast Pyrolysis Technology for Producing Bio-oil}

Fast pyrolysis is an effective method to convert biomass into liquid products (biooil) with yields as high as $75 \%$ wt $\%$ on wet 
Int.J.Curr.Res.Aca.Rev.2016; 4(10): 47-57

basis of feedstock used (Kuye and Edeh, 2013) and has been researched for almost four decades. According to Bridgwater (2012), any form of biomass can be considered for fast pyrolysis and over 100 different biomass types have been tested by many researchers in different countries, ranging from agricultural wastes, energy crops, forestry wastes, and solid and municipal wastes such as sewage sludge and leather wastes.

Also, a large number of organisations are active in research on fast pyrolysis with considerable growth and expansion of activities with more innovation in the types of reactor being investigated. A comprehensive review of existing bio-oil production and research facilities across the world have been compiled as shown in Table.1. Meier et al., (2013) focussed on recent activities in the six member countries of International Energy Agency (IEA) task force of bioenergy activity: Canada, Finland, Germany, UK and USA; while Bridgwater (2012) gave an overview of the activities in other countries in Asia, America, and Europe.

Although, there are few commercial fast pyrolysis plants in the world, the various process technologies are not fully developed (Mictchell, 2011). Hence further studies are required to improve its reliability, performance, product consistency and product characteristics.

A major unit of a bio-oil production system is the reactor. Most research and development has focused on studying and testing bio-oil production with different reactor types using different feedstocks (Bridgwater, 2012) and some of the previous works are summarised in Table.2. The goal is to increase bio-oil yield and quality by optimizing essential reactor characteristics including; heating rates, heating temperatures, and residence time. Each reactor design has unique performance, product yield capacity, advantages, and limitations. These reactors include fixed beds, bubbling fluidized beds, transported beds, conical spouted beds, cyclones, microwaves, ablative reactors, auger and vacuum reactors. For brevity, the detailed description of these reactors is not included here; however, Table. 3 provides a comprehensive comparison of the various reactors.

Meier et al., (2013) outlined the necessary conditions for all reactor configurations to produce high yield of bio-oil from biomass sources using fast pyrolysis as: High heat transfer rates; small particle size of less than 2000 um; optimum reaction temperatures of about $500{ }^{\circ} \mathrm{C}$; rapid cooling of vapor; short residence time of vapor and char in reactor. However, it has been found that particle size and vapour residence time have little effect on bio-oil yield but rather do affect bio-oil quality (Jahirul et al., 2012).

\section{Technical challenges}

There are a number of technical challenges facing the production of bio-oil using fast pyrolysis in Nigeria. These challenges can be categorised as design, fabrication, operational, and analytical challenges.

\section{Fast pyrolysis system design}

The appropriate chemical and mechanical engineering design of the various units involved in fast pyrolysis is essential for the efficient conversion of biomass to bio-oil. The detailed designs of these units are however not available in open literature (Isahak et al., 2012) and several studies are currently on-going to fully understand the design of these systems. The high heat 
transfer rate that is necessary to heat the particles sufficiently imposes a major design requirement on achieving the high heat fluxes required to match the high heating rates and endothermic pyrolysis reactions. It is reported that faster heating rates at optimum pyrolysis temperature maximize the yield of bio-oil (Chiaramonti et al., 2007; Meier et al., 2013) while low heating rates favour the formation of char ((Wang et al., 2005; Uzun and Sarioglu, 2009). Goyal et al.(2008), recommended heating rate of about $300{ }^{\circ} \mathrm{C} / \mathrm{min}$ for fast pyrolysis.

\section{Reaction temperature}

Pyrolysis temperature has a significant influence on pyrolysis products yield, including liquid, gas, and char (Scott et al., 1998; Beis et al., 2002; Kuye and Edeh, 2013). The liquid yields can be divided into organic and reaction water yields. The organic yields reach a maximum at approximately $500^{\circ} \mathrm{C}$ and further temperature increase results in a reduction of liquid yields. In contrast, reaction water yields rise with an increase in temperature. In the case of gas yields, an increase is observed with rising temperature. The opposite trend is observed with char yields (Aguado et al., 2000; Pattiya, 2011; Bok et al., 2012; Salehi et al., 2013). The increase in temperature enhances secondary cracking of pyrolysis vapours; thus the gas yields increase while the char decreases. Controlling the process to ensure stable optimum reaction temperature is important in maximizing bio-oil yield and quality.

\section{Residence time of volatile products and quenching rate}

The design of fast pyrolysis system requires that hot vapours leave the reactor quickly (short residence time) and are rapidly cooled. The time and temperature profile between formation of pyrolysis vapours and their quenching influences the composition and quality of the liquid product. High temperatures will continue to crack the vapours and the longer the vapours are at higher temperatures, the greater the extent of cracking. Rapid cooling of pyrolysis vapour is still a major challenge in fast pyrolysis.

\section{Char/Ash removal}

Char removal is believed to be the most important factor in bio-oil quality and subsequent upgrading processes. These will affect any downstream upgrading of the biooil (Bridgwater, 2013). The ash content of biomass has an impact on organic liquid yields through primary and secondary catalytic cracking reactions of the organic vapours. This results in increased water and carbon dioxide and reduced organic yields. Although the total liquid remains about the same, the water content is much higher possibly resulting in phase separation and the heating value is lower due to the higher water content. Therefore, it is imperative to design a fast pyrolysis system to ensure efficient separation of char from the vapour stream before condensation.

\section{Operational challenges}

\section{Moisture content of feedstock}

High moisture content affects the quality of the final products by increasing the moisture content (Asadullah et al., 2008). It also increases the energy demand for the pyrolysis process since water is first removed before decomposition of the biomass starts (Pattiya and Suttibak, 2012). Moisture content of feedstock should not exceed $15 \mathrm{wt} \%$ during fast pyrolysis (Dobele et al., 2007), however, feedstock with less than $10 \%$ water are recommended (Bridgwater, 1999). 
Int.J.Curr.Res.Aca.Rev.2016; 4(10): 47-57

Table.1 List of some fast pyrolysis systems currently operational (Bridgwater, 2012; Meier, 2013)

\begin{tabular}{|c|c|c|c|}
\hline Fast Pyrolysis Reactor & Organisation & Type of activity & Country \\
\hline \multirow{13}{*}{ Fluid bed } & Agritherm, & Industrial & Canada \\
\hline & Biomass Engineering Ltd & Industrial & UK \\
\hline & Dynamotive & Industrial & Canada \\
\hline & RTI & Industrial & Canada \\
\hline & Adelaide University & Research & Australia \\
\hline & Aston University & Research & UK \\
\hline & Cirad & Research & France \\
\hline & Curtin University & Research & Australia \\
\hline & $\mathrm{ECN}$ & Research & Netherlands \\
\hline & $\begin{array}{l}\text { East China Univ. Science and } \\
\text { Technology }\end{array}$ & Research & China \\
\hline & Gent University & Research & Belgium \\
\hline & $\begin{array}{l}\text { Guangzou Institute of energy } \\
\text { conversion }\end{array}$ & Research & China \\
\hline & \begin{tabular}{|l|l|l} 
Harbin Institute of \\
Technology
\end{tabular} & Research & USA \\
\hline \multirow{3}{*}{ Spouted Fluid bed } & Ikerlan & Industrial & Spain \\
\hline & $\begin{array}{l}\text { Anhui University of Science } \\
\text { and } \\
\text { Technology }\end{array}$ & Research & China \\
\hline & University of Basque & Research & Spain \\
\hline \multirow{6}{*}{$\begin{array}{l}\text { Transported (Circulating) } \\
\text { Bed }\end{array}$} & Ensyn & Industrial & Canada \\
\hline & CPERI & Research & Greece \\
\hline & Metso/UPM & Industrial & Finland \\
\hline & $\begin{array}{l}\text { Guangzhou Inst. Energy } \\
\text { Conversion }\end{array}$ & Research & China \\
\hline & University Birmingham & Research & UK \\
\hline & VTT & Research & Finland \\
\hline Rotating cone & BTG & Research & Netherlands \\
\hline Vortex & TNO & Research & Netherlands \\
\hline \multirow{4}{*}{ Ablative } & Aston University & Research & UK \\
\hline & $\begin{array}{l}\text { Institute of Engineering } \\
\text { Thermophysics, }\end{array}$ & Research & Ukraine \\
\hline & Latvian State Institute, & Research & Latvia \\
\hline & $\begin{array}{l}\text { Technical University } \\
\text { Denmark }\end{array}$ & Research & Denmark \\
\hline \multirow[t]{4}{*}{ Auger } & Abritech, & Industrial & Canada \\
\hline & KIT (FZK) & Research & Germany \\
\hline & Mississippi State University & Research & USA \\
\hline & Michigan State University & Research & USA \\
\hline
\end{tabular}


Int.J.Curr.Res.Aca.Rev.2016; 4(10): 47-57

Table.2 Summary of some previous works on fast pyrolysis

\begin{tabular}{|l|l|l|l|l|}
\hline Feedstock & Pyrolysis & $\begin{array}{l}\text { Type of } \\
\text { reactor }\end{array}$ & Yield, wt \% & Reference \\
\hline Cherry seed & Slow & Fixed bed & 22 & Duman et al., 2011 \\
\hline Cocoa pod & Slow & Fixed bed & 13.8 & Ogunjobi and Lajide, 2015 \\
\hline Corn cob & Fast & Fluidized bed & 61.6 & Mullen et al., 2010 \\
\hline Furniture sawdust & Fast & Fluidized bed & 65.0 & Heo et al., 2010 \\
\hline Grape baggase & Fast & Fixed-bed & 27.6 & Demiral and Ayan, 2011 \\
\hline Maple & Flash & & 64.68 & Goyal et al., 2008 \\
\hline Palm fruit bunches & Slow & Fixed bed & & Ogunsina, et al., 2012 \\
\hline Pine wood & Fast & $\begin{array}{l}\text { Tubular } \\
\text { vacuum }\end{array}$ & 55.0 & Ortega et al., 2011 \\
\hline Pine wood sawdust & Fast & $\begin{array}{l}\text { Conical } \\
\text { Spouted bed }\end{array}$ & 75.0 & Amutio et al., 2012 \\
\hline Poplar aspen & Flash & & 71.2 & Goyal et al., 2008 \\
\hline Sugarcane baggase & Fast & Fixed bed & 56.0 & Islam et al., 2010 \\
\hline Wood sawdust & Microwave & Microwave & 30.0 & Miura et al., 2004 \\
\hline Wood sawdust & Fast & $\begin{array}{l}\text { Cyclone } \\
\text { reactor }\end{array}$ & 74.0 & Lede et al., 2007 \\
\hline Wood Sawdust & Fast & Fluidized bed & 61.7 & Salehi et al., 2013 \\
\hline Yellow corn cob & Slow & Fixed bed & 10.2 & Ogunjobi and Lajide, 2013 \\
\hline
\end{tabular}

Table.3 Advantages, disadvantages and bio-oil yield of some reactors

\begin{tabular}{|c|c|c|c|}
\hline Reactor Type & Advantages & Limitations & Oil Yield \\
\hline Ablative & - Inert gas is not required & $\begin{array}{ll}\text { - } & \text { Reactor is costly } \\
\text { - } & \text { Low reaction rate }\end{array}$ & $70 \%$ \\
\hline Auger & $\begin{array}{ll}\text { - } & \text { Compact } \\
\text { - } & \text { No carrier gas } \\
\text { - } & \text { Lower process } \\
& \text { temperature } \\
\end{array}$ & $\begin{array}{ll}\text { - } & \text { Moving parts in hot } \\
\text { zone } \\
\text { - } \\
\text { Heat transfer is } \\
\text { suitable for small scale }\end{array}$ & $30-50 \%$ \\
\hline $\begin{array}{l}\text { Bubbling } \\
\text { fluidised bed }\end{array}$ & $\begin{array}{ll}\text { - } & \text { Simple design } \\
\text { - } & \text { Easy operation } \\
\text { - } & \text { Suitable for large scale }\end{array}$ & $\begin{array}{l}\text { - Small particle sizes are } \\
\text { needed }\end{array}$ & $50-65 \%$ \\
\hline $\begin{array}{l}\text { Circulating } \\
\text { fluidised bed }\end{array}$ & $\begin{array}{ll}\text { - } & \text { Well-understood } \\
\text { technology } \\
\text { - } & \text { Good control } \\
\text { - } & \text { Large particle sizes can } \\
\text { be used }\end{array}$ & $\begin{array}{l}\text { - Suitable for small scale } \\
\text { - Complex } \\
\text { hydrodynamics } \\
\text { - Char is finer }\end{array}$ & $50-65 \%$ \\
\hline $\begin{array}{l}\text { Conical Spouted } \\
\text { bed }\end{array}$ & $\begin{array}{l}\text { - } \text { Compact and low cost } \\
\text { - High heat transfer } \\
\text { - } \quad \text { Short gas residence time }\end{array}$ & $\begin{array}{l}\text { - Complex design } \\
\text { - High impurities in the } \\
\text { oil } \\
\text { - High temperature }\end{array}$ & $70-75 \%$ \\
\hline
\end{tabular}


Int.J.Curr.Res.Aca.Rev.2016; 4(10): 47-57

\begin{tabular}{|c|c|c|c|}
\hline & & required & \\
\hline Fixed bed & $\begin{array}{ll}\text { - } & \text { Simple design } \\
\text { - } & \text { Reliable } \\
\text { - } & \text { Biomass size } \\
& \text { independent } \\
\end{array}$ & $\begin{array}{l}\text { - Long solid residence } \\
\text { time } \\
\text { - Difficult to remove } \\
\text { char }\end{array}$ & $35-50 \%$ \\
\hline Microwave & $\begin{array}{ll}\text { - } & \text { High heating rate } \\
\text { - } & \text { Large size biomass can } \\
\text { be processed } \\
\text { - } \quad \text { Uniform temperature } \\
\text { distribution } \\
\text { - } \quad \text { High temperature }\end{array}$ & $\begin{array}{l}\text { - High electrical power } \\
\text { consumption } \\
\text { - }\end{array}$ & $30-70 \%$ \\
\hline $\begin{array}{l}\text { Rotating } \\
\text { Cone }\end{array}$ & $\begin{array}{l}\text { - No carrier gas required } \\
\text { - Less wear }\end{array}$ & $\begin{array}{l}\text { - } \text { Complex process } \\
\text { - Small particle } \\
\text { - Small scale }\end{array}$ & $65-75 \%$ \\
\hline Vacuum & $\begin{array}{ll}\text { - } & \text { Produces clean oil } \\
\text { - } & \text { Can process larger } \\
& \text { particles of 3-5cm } \\
\text { - } & \text { No carrier gas required } \\
\text { - } & \text { Lower temperature } \\
& \text { required } \\
\text { - } & \text { Easier liquid } \\
& \text { condensation }\end{array}$ & $\begin{array}{l}\text { - } \\
\text { - } \\
\text { Solid residence time is } \\
\text { too high } \\
\text { - } \\
\text { Require large scale } \\
\text { equipment } \\
\text { - } \\
\text { Poor heat and mass } \\
\text { transfer rate } \\
\text { - } \\
\text { Generates more water }\end{array}$ & $35-50 \%$ \\
\hline
\end{tabular}

\section{Particle size of biomass}

Particle size of biomass feedstock has a major influence on the heating rate, making it an important parameter controlling the rates of drying and primary pyrolysis (Isahak et al., 2012). Jahirul et al (2012) argues that particle size does not affect the yield but rather the quality of the bio-oil and therefore does not have to be less than $1 \mathrm{~mm}$ as reported by other researchers. This is consistent with the works of (Garcia-Perez et al., 2008) who reported that, biomass particle size affects pyrolytic water content of the bio-oil. For fluidised bed reactors the particle size can be between 2-6 mm (Jahirul et al., 2012) since further processing will increase cost. Pattiya and Suttibak (2012) recommended that too small particle size range of biomass should be avoided when producing bio-oil from fast pyrolysis, since fine biomass particles tend to be blown or entrained out of the reaction zone prior to complete pyrolysis. since further processing of feedstock will increase cost. Pattiya and Suttibak (2011) recommended that too small particle size range of biomass should be avoided when producing bio-oil from fast pyrolysis, since fine biomass particles tend to be blown or entrained out of the reaction zone prior to complete pyrolysis.

\section{Fabrication of equipment}

Another major challenge apart from the detailed design of the units is the fabrication of the designed units. Once the hurdle of design has been crossed, there is the need to fabricate some parts of the equipment locally to standard specifications. Since fast pyrolysis is an air-tight and high temperature operation, the fabrication of such equipment requires special skills and machines. There 
are only few fabrication workshops in Nigeria that have such machines.

\section{Conclusion}

Fast pyrolysis bio-oil is an attractive alternative to vegetable oil and animal fat for the production of biofuels in Nigeria. It presents several benefits including waste management to Nigeria where waste treatment is a major challenge. Bio-oil can be produced from virtually any biomass and the fast pyrolysis process for producing biooil is relatively new compared to other thermochemical conversion processes. The process can theoretically yield up to $80 \% \mathrm{wt}$ of bio-oil from biomass on wet basis.

There are prospects for producing bio-oil from lignocellulosic biomass in Nigeria. There are several technologies including fast pyrolysis which could be domesticated to suit country specific situation. The challenge in Nigeria is that very little work has been done to understand the design, fabrication and operation of fast pyrolysis equipment for the production of bio-oil. The only way to bridge this gab is to build technical capacity by way of applied research. Design, fabrication and operation of bench scale pyrolysis system from first principles can serve as a basis to understand and solve the challenges associated with fast pyrolysis such as heat supply and heating rate, char removal, rapid vapour cooling, and vapour residence time.

\section{References}

Aguado, R., Olazar, M., Jose, M.J.S, Aguirre, G., and Bilbao, J. 2000. Pyrolysis of sawdust in conical spouted bed reactor. Yields and product composition. Ind. Eng. Chem. Res., 39: 1925-1933.
Aina, O.M. 2006. Wood waste utilisation for energy generation. Proceedings of the International Conference on Renewable Energy for Developing Countries.

Amuito, M., Lopez, G., Aguado, R., Artetxe, M., Bilbao, J., and Olazar, M. 2012. Kinetic study of lignocellulosic biomass oxidative pyrolysis. Fuel, 95: 305-311.

Antwi, E., Ahiekpor, J., Bensah, E.C., Quansah, D.A., and Arthur, R. 2010. Ghana's biofuels policy: challenges and the way forward. Int. J. Energy and Environ., 1(5): 805-814.

Asadullah, M., Rahman, M.A., Ali, M. M., Motin, M.A., Sultan, M. B., Alam, M.R., and Rahman, M.S. 2008. Jute stick pyrolysis for bio-oil production in fluidized bed reactor." Biores. Technol., 99: 44-50.

Beis, S.H., Onay, O.,and Kockar, O.M. 2002. Fixed bed pyrolysis of safflower seed: influence of pyrolysis parameters on product yields and compositions." Renewable Energy, 26: 21-32.

Bok, J.P., Choi, H.S, Choi, Y.S., Park, H.C., and Kim, S.J. 2012. Fast pyrolysis of coffee grounds: Characteristics of product yields and biocrude oil. Energy, 47: 17-24.

Bridgwater, A.V. 2012. A review of fast pyrolysis of biomass and product upgrading: Biomass and Bioenergy, 38: 68-94.

Bridgwater, A.V. 2013. Report with a process scheme for hydrotreating catalytically produced bio-oil and esterifying bio-oil with alcohols and producing fuel gas for power production or synfuels production. DIBANET.

Bridgwater, A.V., and Peacocke, G.V.C. 2000. Fast pyrolysis processes for biomass." Renewable and Sustainable 
Energy Reviews, 4: 1-73.

Chiaramonti, D., Oasmaa, A., and Solantausta, Y. 2007. Power generation using fast pyrolysis liquids from biomass. Renewable and Sustainable Energy Reviews, 11: 1056-1086.

Demiral, I., and Ayan, E.A. 2011. Pyrolysis of grape bagasse. Effect of pyrolysis conditions on the product yields and characterization of the liquid product. Biores. Technol., 102: 3946-3951.

Dobele, G., Urbanovich, I., Volpert, A., Kampars, V., and Samulis, E. 2007. Fast pyrolysis Effect of wood drying on the yield and properties of bio-oil. Biores., 2: 699-706

Duman, G., Okutucu, C., Ucar, S., Stahl, R., and Yanik, J. 2011. The slow and fast pyrolysis of cherry seed. Biores. Technol., 102: 1869-1878.

Garcia-Perez, M., Wang, X.S., Shen, J., Martin J. R., Tian, F., Woo-Jin, L.,Wu, H., and Li, C.Z. 2008. Fast Pyrolysis of Oil Mallee Woody Biomass: Effect of Temperature on the Yield. Ind. Eng. Chem. Res., 47: 18461854

Goyal, H.B., Seal, D., and Saxena, R.C. 2008. Biofuels from thermochemical conversion of renewable sources: A review. Renewable and Sustainable Energy Rev., 12: 504-517.

Heo, H.S., Park, H.J., Park, Y.K., Ryu, C., Suh, D.J., and Suh, Y.W. 2010. Biooil production from fast pyrolysis of waste furniture sawdust in a fluidized bed. Biores. Technol., 101: 91-96.

Iderawumi, A.M., Olusola, O.S., and Friday, C.E. 2012. Integrated Application of Urea and Sawdust Ash: Effect on soil chemical properties, plant nutrients and sorghum performance. J. Agri. Vet. Sci., 1(4): 38-41.

International Energy Agency (IEA) 2010. Sustainable production of second generation biofuels: potential and perspective in major economies and developing countries. Information paper. Paris, France.

Isahak, M.N.R.W., Hisham,M.W.M., Yarmo, M.A., and Hin, T-y. Y. 2012. Review on bio oil production from biomass by using fast pyrolysis method. Renewable and Sustainable Energy Reviews, 16: 5910-5923.

Islam, M.R., Parveen, M., and Haniu, H. 2010. Properties of sugarcane wastederived bio-oils obtained by fixedbedfire-tube heating pyrolysis. Biores. Technol., 101: 4162-4168.

Izah, S.C., and Ohimain, E.I. 2013.The challenge of biodiesel production from oil palm. Greener J. Biol. Sci., 3(1): 112.

Jahirul, M.I., Rasul, M.G., Chowdhury, A.A. and Ashwath, N. 2012. Biofuels production through pyrolysis - A technological review. Energies, 5: 4952-5001.

Kemausuor, F., Kamp, A., Thomsen, S.T., Bensah, E.C., and Ostergard, H. 2014). Assessment of biomass residue availability and bioenergy yield in Ghana. Resources, Conservation and Recycling, 86: 28-37.

Kuye, A.O., and Edeh, I. 2013. Production of bio-oil from biomass using fast pyrolysis: A critical review. $J$. Minerals Res., 1(1): 01-20.

Kwon, G.J., Kim, D.Y., Kimura, S, and Kuga, S. 2007. Rapid-cooling, continuous-feed pyrolyzer for biomass processing: Preparation of levoglucosan from cellulose and starch. J. Analytical and Appl. Pyrolysis, 80: 1-5.

Lede, J., Broust, F., Ndiaye, F.T., and Ferrer, M. 2007. Properties of bio-oils produced by biomass fast pyrolysis in a cyclone reactor. Fuel, 86: 18001810. 
Meier, D., Beld, B.V., Bridgwater, A.V., Elliott, D., Oasmaa, A., and Preto, F. 2013. State-of-the-art of fast pyrolysis in IEA bioenergy memeber countries. Renewable and Sustainable Energy Rev., 20: 619-641.

Mitchell, D. 2011. Biofuels in Africa Opportunities, Prospects, and Challenges. Washington, DC: The International Bank for Reconstruction and Development / The World Bank.

Miura, M., Kaga, H., Sakurai, A., Kakuchi, T., and Takahashi, K. 2004. Rapid pyrolysis of wood block by microwave heating. J. Anal. Appl. Pyrolysis, 71: 187-199.

Mullen, C.A., Boateng, A.A., Goldberg, N.M., Lima, I.M., Laird, D.A., and Hicks, K.B. 2010. Bio-oil and bio-char production from corn cobs and stover by fast pyrolysis." Biomass and Bioenergy, 34: 67-74.

Nigeria Energy Commission. 2010. Nigerian Bio-Fuel Policy and Incentives.

Ogunjobi, J.K., and Lajide, L. 2013. Characterisation of bio-oil and biochar from slow pyrolysed Nigerian yellow and white corn cobs. $J$. Sustainable Energy and Environ., Taylor and Francis, 4: 77-84.

Ogunsina, B.S., Ojolo, S.J., Ohunakin, O.S., Oyedeji, O.A., Matanmni, K.A., and Bamgboye, I.A. 2012. Potentials for generating alternative fuels from empty palm bunches by pyrolysis. Proc. ICCEM., 185-190.

Okorie, O., Edem, U.B., Edeh, I, and Kuye, A. 2015. Pretreatment of rubber tapping Heava brasiliensis) and Achi Mkpuru Gosswielerodendron balsamiferum) Hardwood sawdust for bio-oil production: drying and particle size characteristics at different temperatures." Petroleum Technol. Development Fund J., In press.

Ortega, J.V., Renehan, A.M., Liberatore,
M.W., and Herring, A.M. 2011. Physical and chemical characteristics of aging pyrolysis oils produced from hardwood and softwood feedstocks." J. Analytical and Appl. Pyrolysis, 91: 190-198.

Pattiya, A. 2011. Bio-oil production via fast pyrolysis of biomass residues from cassava peels in a fluidised-bed reactor. Biores. Technol., 102: 19591967.

Pattiya, A., and Suttibak, S. 2012. Production of bio-oil via fast pyrolysis of agricultural residues from cassava plantations in a fluidised-bed reactor with a hot vapour filtration unit. $J$. Anal. Appl. Pyrolysis, 95: 227-235.

Popoola, L.T., Gutti, B., and Adeniran, J.A. 2013. The potentials of waste-toenergy system in Nigeria: A study of pyrolysis conversion of wood residue to bio-oil in major cities of southwestern Nigeria. Adv. Appl. Sci. Res., 4: 243-251.

Rasul, M.G., and Jahirul, M.I. 2013. Recent Developments in Biomass Pyrolysis for Bio-Fuel Production: Its Potential. Recent Res. Environ. Geol. Sci., 20: 256-265.

Renewable Energy Policy Network for 21st Century 2014. Renweables 2014 Global Status Report.

Ronsse, F., Hecke, Van S., Dickinson, D., and Prins, W. 2013. Production and characterization of slow pyrolysis biochar: influence of feedstock type and pyrolysis conditions. Bioenergy, 5: 104-115.

Salehi, E., Abedi, J., Harding, G.T., and Seyedeyn-Azad, F. 2013. Bio oil from sawdust: Design, operation, and performance of a bench-scale fluidized bed pyrolysis plant. Energy and Fuels, 27: 3332-3340.

Scott, D.S., Piskorz, J., Bergougnou, M.A., Graham., and Overends, R.P. 1998. 
Int.J.Curr.Res.Aca.Rev.2016; 4(10): 47-57

The role of temperature in the fast pyrolysis of cellulose and wood. Industrial and Engineering Chem. Res., 27(1): 8-15.

Uzun, B.B., and Sarioglu, N. 2009. Rapid and catalytic pyrolysis of corn stalks. Fuel Processing Technol., 90: 705716.

Vakkilainen, E., Kuparinen, K., and
Heinimo, J. 2013. Large Industrial users of energy biomass. IEA Bioenergy report.

Wang, X., Kersten, S.R.A., Prins,W.,Van Swaaij, W.P.M. 2005. Biomass pyrolysis in fluidized bed reactor. Part2: Experimental validation of model results. Industrial and Engi. Chem. Res., 44: 8786-8795.

\section{How to cite this article:}

Julius C. Ahiekpor, Ayoade O. Kuye and Osei-Wusu Achaw. 2016. Production of Bio-Oil in Nigeria: Challenges and Prospects. Int.J.Curr.Res.Aca.Rev.4(10): 47-57. doi: http://dx.doi.org/10.20546/ijcrar.2016.410.006 